\title{
Africa as a new potential of the global economy
}

\author{
Aleksandra Milczarek \\ Szczecin University, \\ Poland \\ olamilczarek86@op.pl
}

\begin{abstract}
This article takes up an attempt to confirm the hypothesis, that potential of Africa impacts on its future socio-economic development and is a potential source of economic benefits for investors and exporters from the European Union and other countries of the world. The article discusses the GDP growth changes in the years 2000-2012 and demographic changes that have been evaluated for the construction of a future strong position of this continent. Africa is becoming a significant equal partner and participant in the market process, also shown by the volume of international trade and the influx of foreign direct investments to Africa in recent years. Quantitative data, comparative method and description method have been used to analyse the problem in this article.
\end{abstract}

Keywords: Africa, economic development and growth, demographic trends, international trade

JEL Classification: O55, O11, O40, F40, J11

\section{INTRODUCTION}

Saturation of existing sale markets, considerable gratification of the consumer needs and a continuously growing strong rivalry mean that manufactures and sellers are continually forced to seek new ways of development, new markets and new purchases. It is a common phenomenon to go beyond the country borders in the modern economy. The societies are eliminating consecutive barriers, while at the same time simplifying an international exchange. Flows not only concern the goods, services and material production's factor but also people, knowledge, skills and experience, and even large capital expenditure. These processes are more and more visible in Europe, North America and Asia, contributing to economic growth and development of the various countries and regions of the world. On the other hand these processes are forcing the entrepreneurs to take a step forward and look for the new capital expenditure options. There is a need to find a gap in previous human activity areas, a niche, and then fill it or discover entirely new markets and new consumers. In connection with significant growth of the aforementioned continents, some satisfaction has been provided to people and markets. However the new pearl on the world economic map seems to be Africa, an area which is relatively young with a great economic potential, and not yet fully tapped, but with crucial opportunities. The continent contains countries that are no longer part of the Third World 
and need assistance from the western countries. But still it is very useful and in some areas simply vital. Increasingly, they are dynamically developing countries that are building their political systems and their entire economies. A development of the individual activity sectors is visible. The growing agglomerations and modern infrastructure have appeared (for instance, in Johannesburg). From an economic point of view these countries are becoming equal partners in international trade. Due to its potential Africa is an economically advantageous region, both for investors and exporters, but has not quite yet been discovered. A profit from that kind of collaboration may be a win-win situation. For some it will be bound with sizeable profits; for others it will be synonymous with getting technological and capital support that determines the socioeconomic development.

The purpose of this article is to show the potential of Africa as a determinant for its future socioeconomic development and also the prospective source of economic profits for investors and exporters from the European Union and many other countries of the world. The economic potential of African countries makes them exceptionally favourable regions for business development and make them targets for growing numbers of investments and international trade. The first part of this work describes what Africa has to offer to the modern world and what will build its future growth, becoming a major participant of the global market processes. A further part examines the volume which has changed over the years 2000-2013. It considers the exchange between Africa and other countries. Quantitative data, the comparative method and the description method have been used to analyse the problem in this article.

\section{THE ECONOMIC POTENTIAL OF AFRICA}

Africa has numerous advantages, not only environmental, that create growing interest in this region. On the one hand the continent has not been fully discovered yet by Western civilizations and its secrets and cultural dissimilarity arouse admiration and curiosity. On the other hand a development of relatively young region, emergence of cities and the development of society mean that Africa has a lot to offer the modern world and is becoming an interesting target place for investment activities with promising profits and increasing sale markets. Among the trends currently observed in African countries, the future factors are:

a. A large and still growing GDP

b. Positive population growth

c. Growth of the society in the cities

d. An increase in the working-age population

e. Increasing affluence

f. The development of education

g. Growth of the internal trade

h. Penetration of the mobile market and higher use of the mobile Internet

i. The biggest undeveloped rural acreage in the world.

j. Possession of natural resource (diamonds, gas, black gold etc.)

The most important of these, according to the author, the advantages of Africa, will be discussed in the following sections. 


\subsection{Dynamics GDP growth}

Meter of GDP, gross domestic product, is one of the most widely used measures of economic growth of the country. It includes consumption, investments, government spending and net export. GDP shows the actual economic level of the country, and whether it is growing and moving forward or stagnating and slowing down. Changes in the country production levels show halfway where the economy is going and how the market subjects behave because its actions and decisions affect the form of the meter. Moreover, changeable dynamics of GDP can show what decisions should be taken by the members of the market processes. For instance the period of profitable prosperity is a good time for investing and when crisis appears, it is good to delay any risk venture.

National accounts of African countries are significantly lower than other developed or developing countries in the world. However their values show a clear upward trend. The worth of the national production in Africa is relatively low, however comparing the dynamics of annual changes in the rate of GDP growth put on power, it surpasses the other regions of the world. The dynamics of changes in GDP at constant prices of Africa compared to other areas and the entire world is shown in Figure 1.

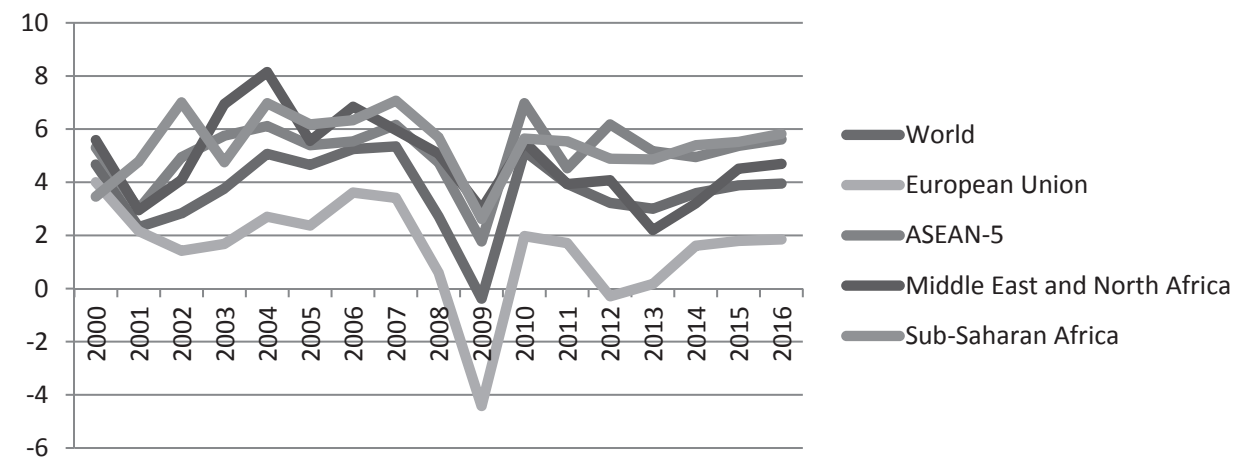

Figure 1. Dynamics GDP changes in chosen world's regions (\%).

Source: based on IMF data.

In the years 2002 -2012 the African economies have been registering positive growth of GDP. The increase in annual production during the period in Sub-Saharan Africa ranged between 4-7 \%. In comparison to other countries, African GDP dynamics in 2001 was higher than both the world GDP and for dynamics production of the EU. In 2013 EU production increased only by about 0,2 \% compared to the previous year, while in Africa by up to 4,9\%. Meanwhile, the global GDP dynamics was 3\%. In 2009 every economy around the world suffered the consequences of the global crisis in 2008, which caused the lower rate of GDP growth. The African economy suffered the lowest fall because it simply did not have closer relations with the European courtiers or USA. Moreover, sub-Saharan countries and North Africa, as well as the Middle East, and Asian countries have shown a positive growth of production, while economic growth in the EU has been negative.

Trend changes of African GDP is very similar to the trend of the countries which are the members of ASEAN-5; that is the five Asian countries (Thailand, Philippines, Indonesia, Malaysia and Vietnam) that belong to the Association of South-East Asian Nations. ASEAN showed bigger rate of changes only in 2003, 2010 and 2012. In recent years Asian countries were shown to be the fastest developing countries. However, 
nowadays Africa has the chance to become the most developed region. In prognosis for the years 2014-2016 IMF (International Monetary Fund) foresees a little GDP growth rate in African countries, especially for sub-Saharan, rather than within the Asian tigers.

Analysis of national accounts in particular countries indicates that of 54 African countries in 2012, in over $40 \%$ of them (23 countries), GDP grew at the rate of over $5 \%$ per year. For comparison, in the same year in the EU with a membership of 28 countries there was only one country that can boast such a dynamics rate. And it was Latvia. 2005 was the better year for 8 countries where the dynamics rate exceeded 5\%.

The economic growth of African countries is often explained by possession of natural resources. About $10 \%$ of global oil reserves, $40 \%$ of gold ore reserves and $80-90 \%$ of chromium and platinum deposits are located in Africa (Chironga, Leke, Lund, Wamelen, 2013-2014). Additionally the continent has the largest acreage of undeveloped farmland, in which only the sub-Saharan area has 600 million hectares (Berman, 2013-2014). Growing demand for natural resources, gas, oil and food gave Africa the ability to develop. For sure rising global demand for minerals, gas, oil and food pose enormous opportunities for Africa. Certainly rise in crude oil prices started at the turn of the century, and maintained to this day, which helps to improve the economic condition of Africa. Growth of the other natural resources such as grain also increased African GDP. Nevertheless, natural resources are not the only growth factor. Revenues from the operation and sales generate about $25 \%$ of GDP. The second part includes mostly the retail and wholesale, transport, communications and productive industry (Chironga, Leke, Lund and Wamelen, 2013-2014).

Thanks to a steady political situation and relief in conflicts, revolts and brotherhoods fights, improvement of the economic condition in Africa was possible. However, even when the wars between the native societies still occur, Africa is perceived to be a region of stability, and there is an opportunity to make business there. In recent years in Africa, the governments limited budget deficitsm which entailed public debt, and caused the better situation of prices. The deficit in 2012 was a little over 3\% with public debt reaching $33 \%$ of GDP. The debt in the EU at the same time was 85\% of GDP (EUROSTAT, 2013). In 2013 the Dark Land has reached a level of 6\% which even in 2000 was over 16\% (IMF, 2014).

African governments have launched pro-growth policies, giving rise to the development of trade and international exchange. System and law regulations have been created, numerous barriers have been abolished, taxes have been reduced and there was privatization of many national enterprises. For example, in Nigeria in 1999-2006 over 116 companies were privatized. Moreover Egypt and Morocco signed an agreement of free trade (Chironga, Leke, Lund, Wamelen, 2013-2014).

The telecommunication branch is experiencing a hilarious prime at the moment. The penetration of the telecommunication branch in 2000 shaped at the level of only $2 \%$, in 2012 reached $78 \%$, and by the year 2015 it is projected to reach 85\%. Over the next 4 years in Sub-Saharan Africa there is also an expected 25-fold growth in mobile Internet (Berman, 2013-2014). The numbers of mobile networks subscribers for every 1000 residents in Africa came to 614 on average. Almost 10 years earlier it was only 43 subscribers. It is worth mentioning that on 1 resident in such countries as Botswana, Gabon, Egypt, Morocco, Libya, Seychelles and South Africa, own(?) more than one phone (EUROSTAT, 2013).

\subsection{Chosen demographic changes in Africa}

The changes that have happened in Africa on the social and demographic ground are the next condition for development of this region and still growing curiosity of that land. Because of the problems in Western countries such as a negative birth rate and aging societies, African countries give hope to meet the needs of the globe for manpower and units which will generate the world's development in the future. 
In 2012 the globe had a population of 7 billion people, of which 1,084 million inhabited Africa. In 2000 there were only 808 million. Interestingly, in the 1990s the population was less numerous than the European population (EUROSTAT, 2013). Medieval dynamics of the population growth on the individual continents, developed in the years 1995-2012 generally in the rage of 1-1,5\%. In Europe it was definitely lower $-0,1 \%$. For the entire world it was $1,2 \%$. The highest rate of population growth was reported in Africa at the level of 2,5\% (GUS, 2012). An upward trend will be observed in the next few years. The world's population in 2012 is illustrated in figure number 2, along with a forecast for the year $2050.60 \%$ of the human population lives in Asia. Africa has the second place spot with 15,3\%. Europe has 10,5\% of the world's population. After nearly 40 years the population from individual continent will decrease. In Africa it will rise. The population in Africa will increase upward of 10 percentage points with several percent or even fractional declines in other regions. So Africa will be have one-quarter of the entire world's population and together with Asia will form a propulsive global economy.

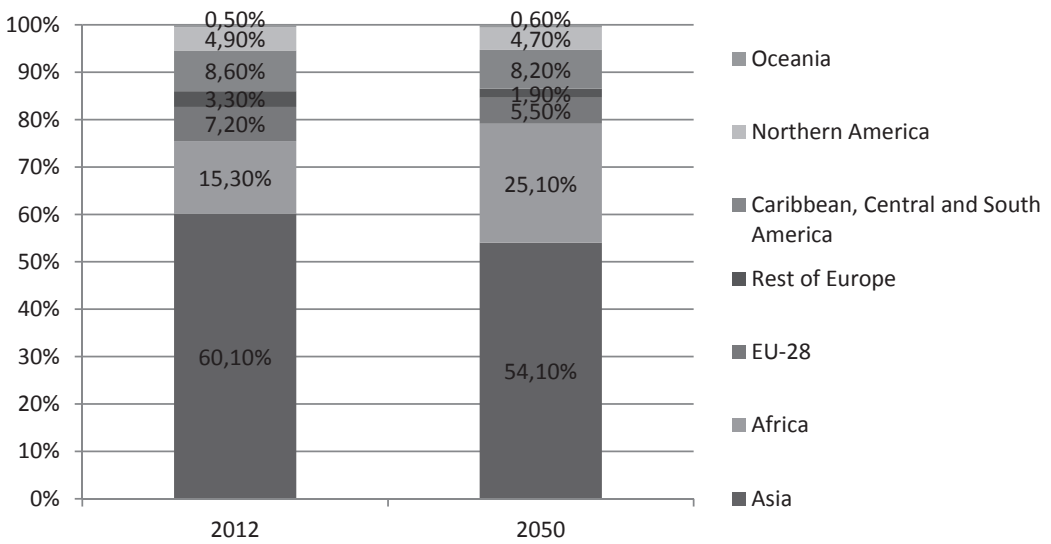

Figure 2. World population in 2012 and its forecast. Source: based on EUROSTAT date.

Unlike European countries Africa has a positive birth rate. In the years 2005-2010 there were 23 births for every 1,000 people, which is twice as high as the world's average and the growth in Asia (GUS, 2012).

The analysis of the human capital is based in particular on those of productive age because they are able to work and generate GDP. According to assumptions in the international statistic, people aged 15-64 are qualified to this group. Its number has been rising year by year in African countries. From 2010-2020 the labor force will increase by 163 million people. The contribution of the productive age population in Africa is positively changing. In 2000 they accounted for $54,5 \%$ of the population, in $2010-56 \%$ and it is projected to be 60\% in 2050. A completely opposite trend is observed globally or in Europe itself. At the beginning of the $21^{\text {st }}$ century, every tenth employer was African and in a half century it will be one in four (GUS, 2012). Due to the low survival rate - the average life expectancy in Africa is 58 years, while in Europe it is 80 - such a labor force dependency ratio will be relatively low. In particular, in the next years the African employees will have fewer dependent people than workers from other countries. There is no doubt that the growing labor force will contribute to long-term growth. However, it is possible only if there will be lots of investments in public capital, high level of education and lifting the level of work. The education 
in Africa is forming at the level of $75 \%$ of children. High schools and Colleges are growing slowly, step by step (Berman, 2013-2014).

Another positive trend is the development of cities and migration of people from rural to urban. In 2000 one-third of the population lived in cities. 10 years later it was 40\% (GUS, 2012). Until 2030, half of the African population will be urban citizens. For comparison, currently $80 \%$ of the European population lives in cities. Over 50 cities in Africa have 1 million inhabitants. So a numerical amount can rival the European cities. Higher wages are a bait for people who are willing to work in cities, especially for higherincome households, which after satisfying the basic needs of food and housing expenses pursue other goods and services, which in cities are more readily available. A growth of consumptive expenses affects higher global demand which makes the production rates higher and that all creates more work places and growth in prosperity. In 200816 million households achieved income at the level of 20 thousand dollars per year. This group could afford to purchase quite luxurious things such as cars, houses and electronics. The incomes from 27 million households were in a group that earned 10-20 thousand dollars per year, and 41 million families earned 5-10 thousand dollars. The last group could afford to buy the various articles but not food (Chironga, Leke, Lund, Wamelen, 2013-2014). The wealth is growing year by year and it is foreseen that the level of consumption will grow. In the next few years the African consumption market may become the world's most dynamic market. This continent needs practically everything, from infrastructure to education, health care, and retail trade with goods and services that enhance comfort and lifestyle. African countries and citizens are able to pay for this right away and it should bring them new investors.

\section{THE AFRICAN TRADE EXCHANGE WITH THE REST OF THE WORLD AND THE DIRECT FOREIGN INVESTMENTS}

A trade between the world and Africa is getting stronger. Relations between the rest of the world and Africa are no longer the relations like: "donor-receiver", but African countries are becoming equal trade partners. African natural resources are the key in trade because the other countries do not have them or have them but in small amounts and simply need them. A number of foreign investments are growing and it is also observed that the world powers are involved in the economy of African countries. These are trying to create stable conditions for the functioning of market participants and open international cooperation as well as within the continent and with the rest of the world.

Africa on its long way to development practically needs everything. Years of underdevelopment have led to the need to use the ideas, innovation and experience of highly developed countries. A growth in social incomes arise a need to buy new goods from abroad. Finally the demand that used to be repressed for many years now can be met. For this reason, Africa becomes a member of trade exchange, as not only a significant importer but also an exporter.

The value of exports and imports of African countries shows a clear upward trend (Figure 3). Over the 12 years export and import increased four-fold. In 2009 because of the crises both values experienced declines with respect to the previous year. Export fell by 156 billion dollars and import by 75 billion. It was the only year when a trade balance was negative (-16 908 million dollars). In subsequent years a trade exchange increased dynamically. At the end of 2012 export amounted to 640,5 billion dollars and import to 613 billion dollars. So far African contribution in trade exchange has shaped a few percentage points, but predictions of its development suggest that this share is increasing. 


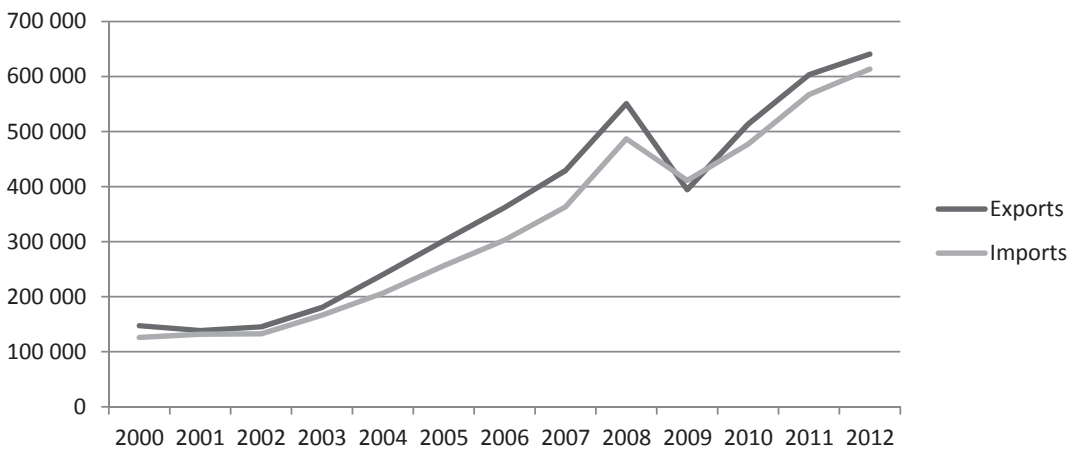

Figure 3. The quantity of import and export (in million \$).

Source: based on UNCTAD data.

Development opportunities are seen by countries such as USA, China, Japan, India, Brazil and the EU. At the beginning of the period almost two thirds of African exports were getting into the European or American market; ten years later it was only 50\%. Imports from the EU and the U.S. accounted respectively for $50 \%$ of goods and services imported into the countries of the Third World in 2001, and below $40 \%$ in 2011. The EU dominates in trade between Africa but this situation is gradually weakening. A trade volume with different countries is growing, especially with China and India but also in international internal trade (Economic Commission for Africa, 2013). The trade between Brazil and Africa in 2012 in comparison to 2000 rose fourteen-fold from 4,6 to 60 billion dollars. China's annual trade with Africa is at the level of 166 billion dollars (Klöckl, 2013).

Interest in Africa is also reflected in strong implementation of foreign direct investment (FDI). FDI inflow in Africa, EU and in Asia are shown in Table 1.

Table 1

Inward foreign direct investment flows (in million \$)

\begin{tabular}{|l|r|r|r|r|r|r|r|r|r|r|r|r|r|}
\hline & \multicolumn{1}{|c|}{2000} & \multicolumn{1}{|c|}{2001} & \multicolumn{1}{|c|}{2002} & 2003 & \multicolumn{1}{|c|}{2004} & 2005 & 2006 & 2007 & 2008 & 2009 & 2010 & 2011 & 2012 \\
\hline AFRICA & 9621 & 19943 & 14613 & 18158 & 17370 & 30913 & 36575 & 51274 & 58894 & 52964 & 43582 & 47598 & 50041 \\
\hline Eastern Africa & 1468 & 1587 & 1713 & 2068 & 2156 & 2585 & 3285 & 6054 & 6242 & 5736 & 7513 & 8951 & 13297 \\
\hline Middle Africa & 1503 & 3690 & 3839 & 6177 & 3603 & 1619 & 2734 & 4663 & 6594 & 8114 & 6119 & 4987 & 2941 \\
\hline Northern Africa & 3250 & 5352 & 3872 & 5261 & 6441 & 12236 & 23194 & 23936 & 23114 & 18224 & 15709 & 8496 & 11502 \\
\hline Southern Africa & 1269 & 7239 & 2274 & 1283 & 1541 & 7298 & 527 & 7066 & 10465 & 6182 & 2265 & 7459 & 5484 \\
\hline Western Africa & 2131 & 2075 & 2916 & 3369 & 3629 & 7174 & 6836 & 9554 & 12479 & 14709 & 11977 & 17705 & 16817 \\
\hline ASIA & 156581 & 122894 & 96062 & 127144 & 166300 & 225004 & 295925 & 364899 & 396152 & 324688 & 400687 & 436150 & 406770 \\
\hline EU27 & 701826 & 385564 & 314630 & 285192 & 227461 & 501687 & 584686 & 859118 & 545325 & 359000 & 379444 & 441557 & 258514 \\
\hline WORLD & 1413169 & 836012 & 626081 & 601246 & 734148 & 989618 & 1480587 & 2002695 & 1816398 & 1216475 & 1408537 & 1651511 & 1350926 \\
\hline
\end{tabular}

Source: based on UNCTAD data.

In 2000 incoming investments to Africa had a value of 9621 million dollars, what was only $0,68 \%$ of all FDI world's value. At the same time, the share of Asia stood at $11.1 \%$ and $49.7 \%$ of the European Union. Over the twenty years the ratios changed. In Europe FDI decreased to 19\% but in Asia increased to 30\% of world's flows. In Africa during the period, FDI recorded a five-fold increase in 2012 as compared to the 
initial which was already 3,7\% of global FDI flows. Additionally the differences between the various regions of the continent have been deepened. Foreign investments flowed mostly in the areas of West Africa and Eastern Europe, quite different than ten years ago, where their movement was the largest in North Africa.

Phrase, which can be expected by entrepreneurs with investments in African countries according to the $\mathrm{UN}$, is higher than in any other emerging countries. Supported by the relatively little competition, a small number of foreign companies and long suppressed demand, which is now released (Chironga, Leke, Lund, Wamelen, 2013-2014). Japan over the next five years plans to invest in Africa for a total amount of 32 billion dollars, of which about 14 million dollars will be spent on development aid to the continent (Klöckl, 2013). Nokia and Coca-Cola have a distribution network in almost every country in Africa. Unilever has been operating in 20 countries, Nestle - 19, Standard Chartered Bank is present in 14, Barclays - 12, and Societe Generale in 15 countries (Chironga, Leke, Lund, Wamelen, 2013-2014). Entities thinking about long-term profits and their brands to ensure a stable market position should be included in the African markets, since they will carry out the segmentation of the market and will impact the structure of industries. This will benefit not only foreign companies but also the domestic market, society and economy of Africa, because it will help them and accelerate their development.

\section{CONCLUSION}

Europe and the rest of the world should not ignore Africa and its potential because from over ten years the continent is permanently growing and developing at a dynamic pace. The GDP growth rate exceeds the growth in European countries and other highly developed countries. The structure and infrastructure changes are visible and although in many ways this area is still unstable and the activity on it is associated with high risk, the global players increasingly take the risk, because the vision is the promise of profits. The first players of this market, foreign investors reap the largest share in the market and will establish appropriate contacts that would later facilitate penetration. Foreign direct investment is growing by leaps and bounds, vigorously developing the company's investment in Africa.

The current potential of Africa is compared to what China had before they became one of the modern economic powers. A major advantage of the continent's population is a relatively young and active population, which is characterized by a positive birth. Another advantage is urbanization. The population moves from rural to urban and generates income, which can freely manage and contribute to the increase in demand and consumption, and thus the production.

Africa is growing in strength. It is becoming an increasingly important partner in international trade, both as an exporter and importer. Growing numbers of the countries around the world are willing to do business with Africa. Forecasts for the African countries are successful in the coming years, and further growth and socio-economic development are expected, and even more dynamic the processes discussed in the text.

\section{REFERENCES}

Berman J. (2013-2014), Siedem powodów, dla których Afryka jest dzisiaj na fali, Harvard Business Review Polska, No. 12/1, pp. 46-47.

Chironga M., Leke A., Lund S. and Wamelen A. (2013-2014), Afryka nowa szansa na wzrost, Harvard Business Review Polska, No. 12/1, pp. 123-131. 
Economic Commision for Africa (2013), Making the Most of Africa's Commodities: Industrializing for Growth, Jobs and Economic Transformation, Economic Report on Africa 2013, Economic Commission for Africa, pp. 48.

EUROSTAT (2013), The European Union and the African Union. A statistical portrait, Luxembourg, Publications Office of the European Union, pp. 10, 11, 60-63, 78.

GUS Główny Urząd Statystyczny (2012), Rocznik Statystyki Międzynarodowej 2012, Warszawa, pp. 38-41.

IMF International Monetary Fund, 24.05.2014, <http://www.imf.org/external/pubs/ft/weo/2014/01/weodata/weorept. aspx?sy $=2000 \&$ ey $=2014 \& s c s m=1 \& s s d=1 \&$ sort $=$ country \&ds $=. \& b r=1 \& p r 1 . x=81 \& p r 1 . y=8 \& c=406 \% 2 C 603 \& s=P$ CPIPCH\%2CGGXWDG_NGDP\&grp=1\&a=1)>

Klöckl H. (2013), Afrikas beste neue Märkte, corporAID Magazin, No.47, pp. 26-28.

UNCTAD United Nations Conference on Trade and Development, 30.05.2014, <http://unctadstat.unctad.org/ TableViewer/tableView.aspx> 